\title{
Oxidation Improvements of Low Sulfur Processed Superalloys
}

\author{
Tammy M. Simpson and Allen R. Price \\ Howmet Research Corporation \\ 1500 South Warner Road \\ Whitehall, Michigan, 49461-1895
}

\begin{abstract}
At the relatively high operating temperatures at which many superalloys are utilized, oxidation is of great concern. Nickel based superalloys tend to form alumina scales that protect the material from further oxidation. The oxidation resistance is reduced, however, when sulfur segregates from the bulk alloy and degrades the alumina layer. Reducing the sulfur level in the alloy material can prevent this from occurring. Howmet Dover Alloy has developed methods for lowering the sulfur content in alloys to less than one ppm using a liquid refining method during the master heat formulation.
\end{abstract}

Both standard production and low sulfur modified single crystal superalloys were subjected to oxidation testing at $1093^{\circ} \mathrm{C}\left(2000^{\circ} \mathrm{F}\right)$ and $1177^{\circ} \mathrm{C}\left(2150^{\circ} \mathrm{F}\right)$ in order to determine to what extent the sulfur affected the oxidation resistance. Alloys were tested both in the coated and the uncoated condition. The three coatings that were evaluated were LDC-2E, MDC-150, and MDC-150L. The LDC-2E coating is the product of a pack-cementation process. The MDC-150 coating is a platinum aluminide coating developed at Howmet, and MDC-150L coating is a low sulfur platinum aluminide coating that was also developed at Howmet. CMSX $-4^{\circledR}$, and CMSX-10 ${ }^{\circledast}$, Rene' $\mathrm{N} 5^{\circledR}$, and PWA $1484^{\circledR}$ alloys were evaluated.

In general, the low sulfur alloys were more oxidation resistant than their production counterparts in both the uncoated and the coated states for all of the alloys evaluated. Reducing the amount of sulfur present in the nickel based alloys did increase the oxidation resistance especially at $1177^{\circ} \mathrm{C}\left(2150^{\circ} \mathrm{F}\right)$. All three coatings were effective at limiting alloy oxidation at $1093^{\circ} \mathrm{C}\left(2000^{\circ} \mathrm{F}\right)$ up to 2000 hours. 


\section{Introduction}

At the relatively high operating temperatures at which many superalloys are utilized, oxidation is of great concern. Nickel based superalloys tend to form alumina scales that protect the material from further oxidation ${ }^{1}$. The oxidation resistance is reduced, however, when sulfur segregates from the bulk alloy and degrades the adhesion of the alumina layer ${ }^{2}$. Lowering the sulfur level in the alloy material can prevent this from occurring ${ }^{3}$. Howmet Dover Alloy has developed methods for lowering the sulfur content in alloys to less than one ppm using a liquid refining method during the master heat formulation ${ }^{4}$. Typical sulfur levels in single crystal superalloys are between two to ten ppm.

\section{Technical Approach}

The alloys, coatings, and testing temperatures used in this experiment are summarized in Table I. Both low sulfur and standard production heats of PWA 1484 and Rene' N5 were produced at Howmet Dover Alloy (HDA). Multiple master heats of the two alloys were produced in sizes ranging from 180 to $2270 \mathrm{~kg}$ (400 to 5,000 pounds) having bulk sulfur levels of $<0.5 \mathrm{ppm}$. In addition, blends of CMSX-4 and CMSX-10 were purchased with different sulfur levels. Each alloy was tested at both temperatures with each coating as well as in the uncoated state. Alloys with the "LS" designation are low sulfur alloys.'Major chemistry differences of the alloys are highlighted in Table $\amalg$. None of the alloys contained the reactive element yttrium.

Table I: Parameters for the Oxidation Experiment

\begin{tabular}{c|c|c}
\hline Alloy* & Coating & Parameters \\
\hline Rene' N5 & LDC-2E & A) $1093^{\circ} \mathrm{C}$ \\
Rene' N5 LS & MDC-150 & 100 hours \\
PWA 1484 & MDC-150L & at temperature \\
PWA 1484 LS & Uncoated & \\
CMSX-4 Blend & & B) $1177^{\circ} \mathrm{C}$ \\
CMSX-4 Virgin & & 50 min heat-up \& \\
CMSX-10 Virgin & & 10 min cool-down \\
\hline
\end{tabular}

* LS stands for low sulfur

The LDC-2E coating is the platinum aluminide product of a pack-cementation process. The MDC-150 coating is a platinum aluminide coating developed at Howmet, and the MDC-150L coating is a low sulfur platinum aluminide coating that was also developed at Howmet. These coatings are deposited via chemical vapor deposition. The LDC-2E and MDC 150 are high activity coatings, whereas the MDC$150 \mathrm{~L}$ is a low activity coating ${ }^{5}$. The aluminum activity affects the direction of diffusional growth ${ }^{5}$.
Table II: Main Elemental Differences Among the Alloys

\begin{tabular}{c|c|c|c|c}
\hline Element & $\begin{array}{c}\text { Rene' } \\
\text { N5 }\end{array}$ & $\begin{array}{c}\text { PWA } \\
1484\end{array}$ & $\begin{array}{c}\text { CMSX- } \\
4\end{array}$ & $\begin{array}{c}\text { CMSX- } \\
10\end{array}$ \\
\hline $\mathrm{Al}$ & 6.2 & 5.7 & 5.6 & 5.7 \\
\hline $\mathrm{Co}$ & 7.5 & 10.0 & 10.0 & 3.3 \\
\hline $\mathrm{Cr}$ & 7.0 & 5.0 & 6.5 & 2.3 \\
\hline $\mathrm{Mo}$ & 1.5 & 1.9 & 0.6 & 0.4 \\
\hline $\mathrm{Re}$ & 3.0 & 3.0 & 3.0 & 6.2 \\
\hline $\mathrm{Ta}$ & 6.5 & 8.7 & 6.0 & 8.4 \\
\hline $\mathrm{Ti}$ & $0.04 \max$ & - & 1.0 & 0.22 \\
\hline $\mathrm{W}$ & 5.0 & 5.9 & 6.0 & 5.5 \\
\hline
\end{tabular}

Coupons were prepared from panels cast in each of the alloys. Sulfur levels were measured below 1ppm using a technique developed at Howmet Research Corporation that compares well with glow discharge mass spectrometry (GDMS). Four coupons from each alloy were tested. The coupons were grit blasted prior to coating in order to clean the surface. The coupons were either left in the uncoated state or coated with one of the three coating types.

After coating, the coupons were subjected to a heat treatment to stabilize the coating. Cyclic oxidation testing at $1177^{\circ} \mathrm{C}\left(2150^{\circ} \mathrm{F}\right)$ consisted of 50 minutes of hot time at the designated temperature and 10 minutes of cooling for a total of 2000 hours of testing. At $1093^{\circ} \mathrm{C}\left(2000^{\circ} \mathrm{F}\right)$, the only cooling period occurred when the coupons were weighed. Past oxidation research efforts have shown that the cyclic testing at $1177^{\circ} \mathrm{C}\left(2150^{\circ} \mathrm{F}\right)$ is representative of what is observed in normal operating conditions, only at an accelerated rate. The $1093^{\circ} \mathrm{C}\left(2000^{\circ} \mathrm{F}\right)$ testing condition was chosen because other research has been conducted at that particular temperature.

Periodically the coupons were cooled to room temperature and weighed. Samples were oxidized for a total of 2000 hours. The average weight change was monitored throughout the oxidation test. The weight change was normalized to the surface area of the coating. Depletion zone measurements were made on the uncoated samples. The oxidation resistance of the low sulfur alloy version was compared to the production version.

\section{$\underline{\text { Results and Discussion }}$}

Measurements were made of the depletion zone depth for each of the alloys that completed the uncoated oxidation testing. Table III is a summary of the average depletion zone thickness and final 2000 hour weight change for the $1093^{\circ} \mathrm{C}\left(2000^{\circ} \mathrm{F}\right)$ cycle. This table is not intended to relate alloy performance with depletion zone depth but to show the ability of the lower sulfur containing alloys to form a protective scale that is less susceptible to spallation. As the 
rate of protective scale spallation is reduced, both the depth of alloy depletion and alloy weight loss are decreased.

Table III: Results of $1093^{\circ} \mathrm{C}\left(2000^{\circ} \mathrm{F}\right)$ Oxidation Trials After 2000 hours

\begin{tabular}{c|c|c|c}
\hline Alloy & $\begin{array}{c}\text { Sulfur } \\
\text { Level } \\
(\mathrm{ppm})\end{array}$ & $\begin{array}{c}\text { Avg. } \\
\text { Depletion } \\
\text { Zone Depth }\end{array}$ & $\begin{array}{c}\text { Avg. Final } \\
\text { Wt. Change } \\
\left(\mathrm{mg} / \mathrm{cm}^{2}\right)\end{array}$ \\
\hline Rene' N5 & 3.5 & $0.0011^{\prime \prime}$ & -10.661 \\
Rene' N5 LS & 0.8 & $0.0005 "$ & 0.616 \\
\hline PWA 1484 & 2.5 & $0.0023 "$ & -8.856 \\
PWA 1484 LS & 0.3 & $0.0006 "$ & -0.001 \\
\hline CMSX-4 Blend & 4.1 & $0.0040 "$ & -16.753 \\
CMSX-4 Virgin & 2.6 & $0.0017 "$ & -4.553 \\
\hline CMSX-10 & 1.8 & $0.0021 "$ & -24.329 \\
Virgin & & & \\
\hline
\end{tabular}

The depletion zone data for the $1177^{\circ} \mathrm{C}\left(2150^{\circ} \mathrm{F}\right)$ uncoated oxidation coupons are listed in Table IV. The results were similar to those seen in the $1093^{\circ} \mathrm{C}\left(2000^{\circ} \mathrm{F}\right)$ oxidation cycle, only more pronounced at the higher temperature.

Table IV: Results of $1177^{\circ} \mathrm{C}\left(2150^{\circ} \mathrm{F}\right)$ Oxidation Trials After 2000 hours

\begin{tabular}{c|c|c|c}
\hline Alloy & $\begin{array}{c}\text { Sulfur } \\
\text { Level } \\
(\mathrm{ppm})\end{array}$ & $\begin{array}{c}\text { Avg. } \\
\text { Depletion } \\
\text { Zone Depth }\end{array}$ & $\begin{array}{c}\text { Avg. Final } \\
\text { Wt. Change } \\
\left(\mathrm{mg} / \mathrm{cm}^{2}\right)\end{array}$ \\
\hline Rene' N5 & 3.5 & $0.0074 "$ & -15.396 \\
Rene' N5 LS & 0.8 & $0.0034 "$ & -5.611 \\
\hline PWA 1484 & 2.5 & $0.0100 "$ & -328.878 \\
PWA 1484 LS & 0.3 & $0.0038 "$ & -7.332 \\
\hline CMSX-4 Blend & 4.1 & $0.0110 "$ & -390.581 \\
CMSX-4 Virgin & 2.6 & $0.0074 "$ & -105.827 \\
\hline CMSX-10 & 1.8 & $0.0048 "$ & -567.276 \\
Virgin* & & & \\
\hline
\end{tabular}

* Coupons were removed after 1650 hours due to severe oxidation.

Figures 1 and 2 are optical micrographs of uncoated PWA 1484 after oxidation for 2000 hours at $1177^{\circ} \mathrm{C}\left(2150^{\circ} \mathrm{F}\right)$. Production PWA 1484 is shown in Figure 1, and low sulfur PWA 1484 is shown in Figure 2. The reduced sulfur level helps to maintain the integrity of the protective oxide layer for a greater amount of time.

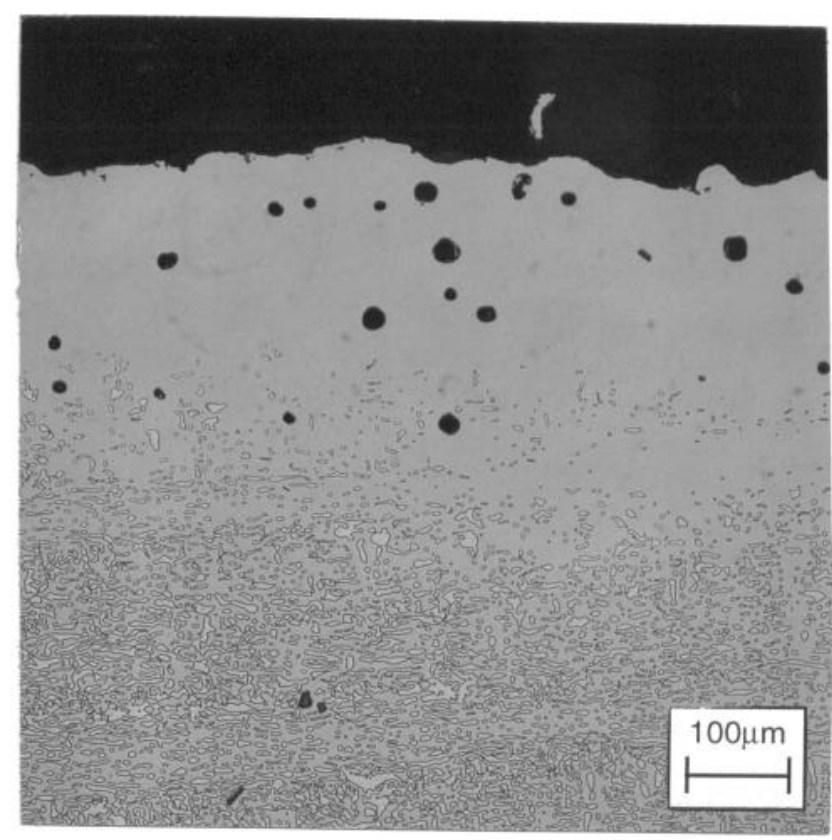

Figure 1: Optical photograph of production PWA 1484 after oxidation for 2000 hours at $1177^{\circ} \mathrm{C}\left(2150^{\circ} \mathrm{F}\right)$.

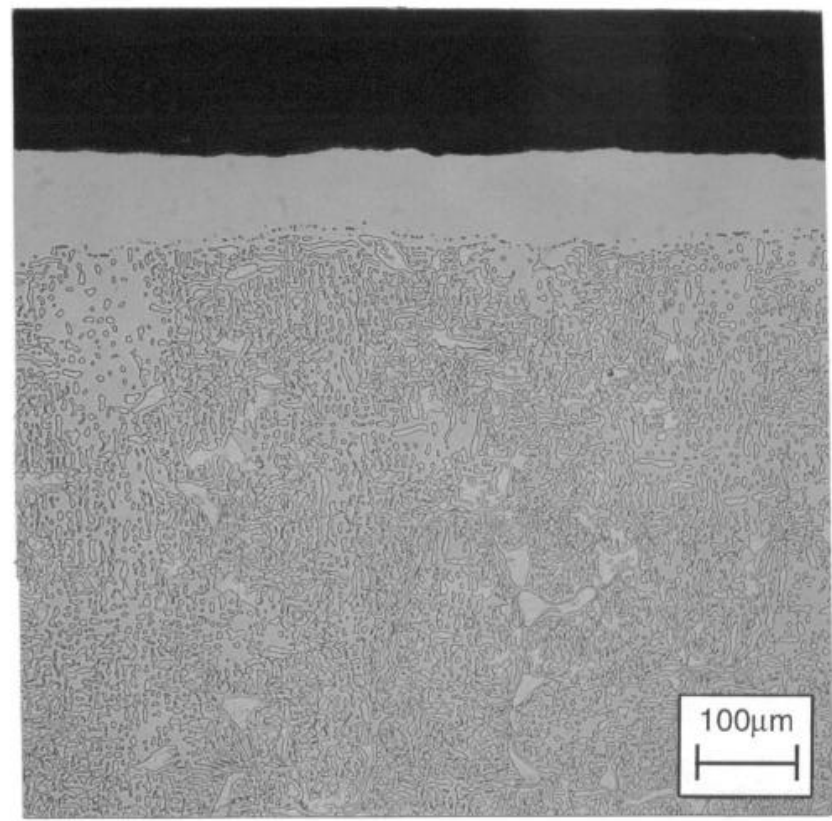

Figure 2: Optical photograph of low sulfur PWA 1484 after oxidation for 2000 hours at $1177^{\circ} \mathrm{C}\left(2150^{\circ} \mathrm{F}\right)$. 
The results for the coated alloys tested at $1177^{\circ} \mathrm{C}\left(2150^{\circ} \mathrm{F}\right)$ are shown in Figures 3 to 6 . Each graph compares the relative oxidation resistance as a measure of weight change for both the low sulfur and the production version of each alloy for all three coating types. Since the various coatings are not the same thickness, weight change results were normalized to the thickness of the coating after post-coat heat treatment to be able to more accurately compare coating effectiveness. Failure was designated as a weight change of zero as compared to the original weight of the coated coupon. Please note that the legends are ordered according to the amount of weight loss at 2000 hours. In addition, "LS" stands for low sulfur processed material and "Prod" stands for production alloy.

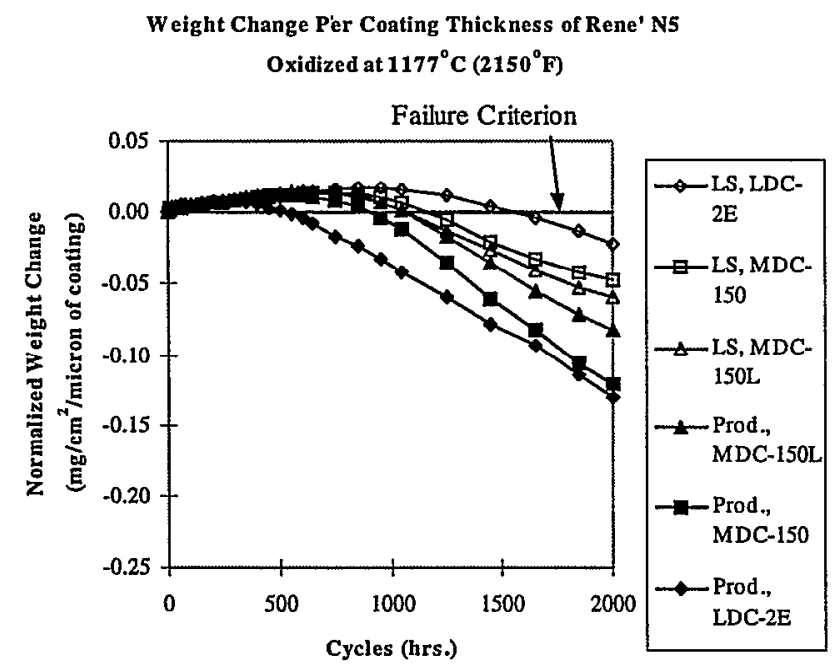

Figure 3: Cyclic oxidation results at $1177^{\circ} \mathrm{C}$ for production and low sulfur versions of coated Rene' N5.

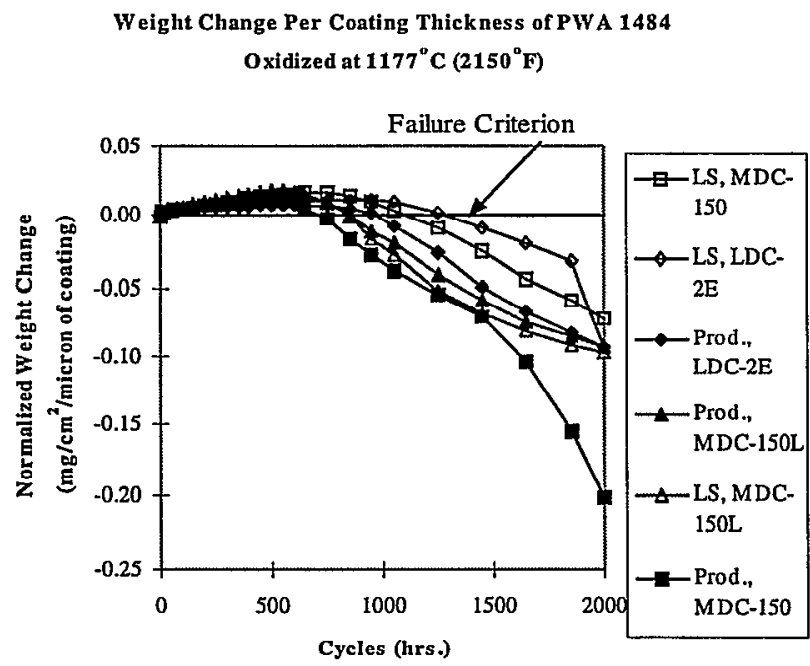

Figure 4: Cyclic oxidation results at $1177^{\circ} \mathrm{C}$ for production and low sulfur versions of coated PWA 1484.

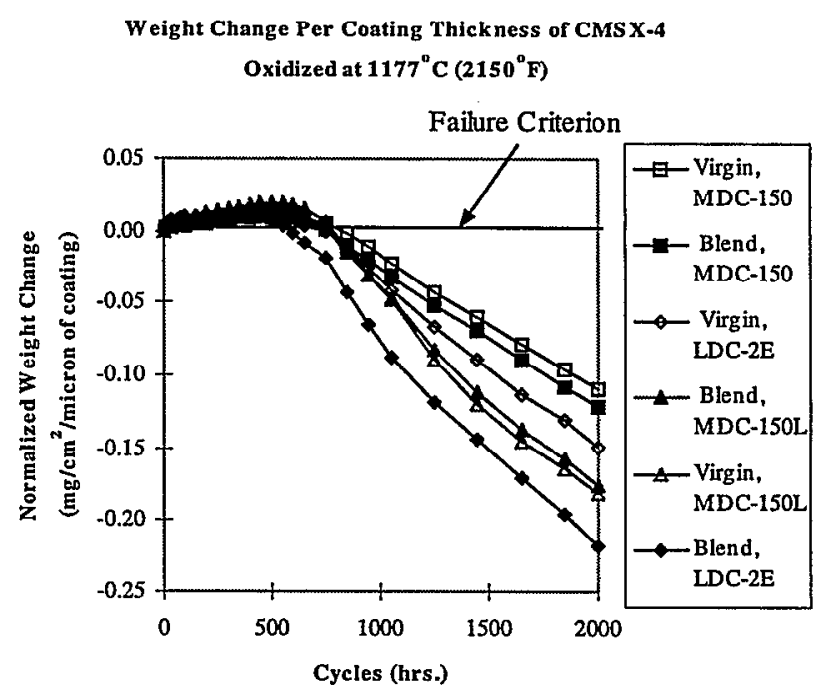

Figure 5: Cyclic oxidation results at $1177^{\circ} \mathrm{C}$ for virgin and blend versions of coated CMSX-4.

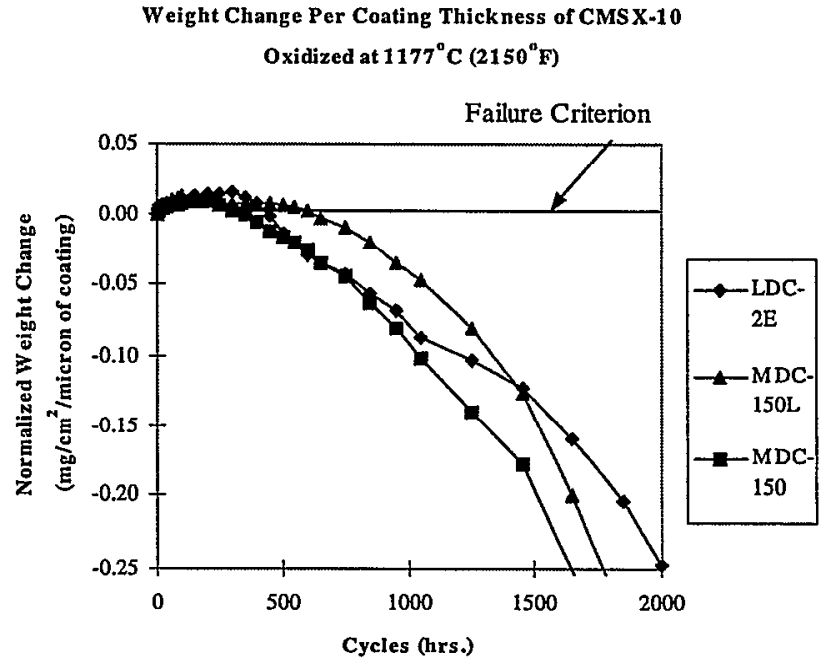

Figure 6: Cyclic oxidation results at $1177^{\circ} \mathrm{C}$ for coated CMSX-10.

Oxidation resistance results at the $1177^{\circ} \mathrm{C}\left(2150^{\circ} \mathrm{F}\right)$ testing temperature are detailed in Table V. Failure was designated as the number of cycles that corresponded to a weight change of zero as compared to the original weight of the coupon prior to oxidation testing. The number of cycles to failure was then divided by the original coating thickness to determine the number of hours of oxidation resistance per micron of coating. In general, the low sulfur alloys were more resistant to oxidation for a longer time period than the production alloys. That trend is more apparent with the LDC-2E and MDC-150 coated samples. However, no differences could be determined between the production and low sulfur versions of the MDC-150L coated samples. 
Table V: Cycles to Failure at $1177^{\circ} \mathrm{C}$ for Each Alloy

\begin{tabular}{c|c|ccc}
\hline \multirow{2}{*}{ Alloy } & $\begin{array}{c}\text { Sulfur } \\
\text { Level } \\
\end{array}$ (ppm) & \multicolumn{4}{|c}{$\begin{array}{c}\text { Cycles to Failure/Micron of Coating } \\
\text { (Hours/Micron of Coating) }\end{array}$} \\
LDC-2E & MDC-150 & MDC-150L \\
\hline Rene N5 & 3.5 & 6 & 10 & 13 \\
N5 LS & 0.8 & 18 & 14 & 14 \\
\hline PWA & 2.5 & 12 & 9 & 12 \\
1484 & & 15 & 14 & 12 \\
\hline 1484 LS & 0.3 & 15 & 7 & 6 \\
\hline $\begin{array}{c}\text { CMSX-4 } \\
\text { Blend }\end{array}$ & 4.1 & 7 & 8 & 6 \\
$\begin{array}{c}\text { CMSX-4 } \\
\text { Virgin }\end{array}$ & 2.6 & 8 & 8 & 5 \\
\hline $\begin{array}{c}\text { CMSX- } \\
10\end{array}$ & 1.8 & 5 & 3 & 5 \\
\hline
\end{tabular}

Most of the alloy systems exhibited excellent oxidation resistance at $1093^{\circ} \mathrm{C}\left(2000^{\circ} \mathrm{F}\right)$ even up to 2000 hours. The only cooling period occurred when the coupons were to be weighed. Periodically (every 100 hours), the samples were cooled to room temperature and weighed. The $1093^{\circ} \mathrm{C}$ $\left(2000^{\circ} \mathrm{F}\right)$ oxidation results for Rene' N5 are detailed in Figure 7. As can be seen, all coated coupons experienced weight gain up to the 2000 hour time period.

Similar results were found with PWA 1484 and CMSX-4 (Figures 8 and 9). The coated CMSX-10 coupons (shown in Figure 10) exhibited a very different behavior. The MDC150 coated coupons had significant weight loss after about 750 hours. The LDC-2E coating had begun to experience a minor amount of weight loss, while the MDC-150L coating continued to gain weight.

\section{Weight Change Per Coating Thick ness of Rene' N5} Oxidized at $1093^{\circ} \mathrm{C}\left(2000^{\circ} \mathrm{F}\right)$

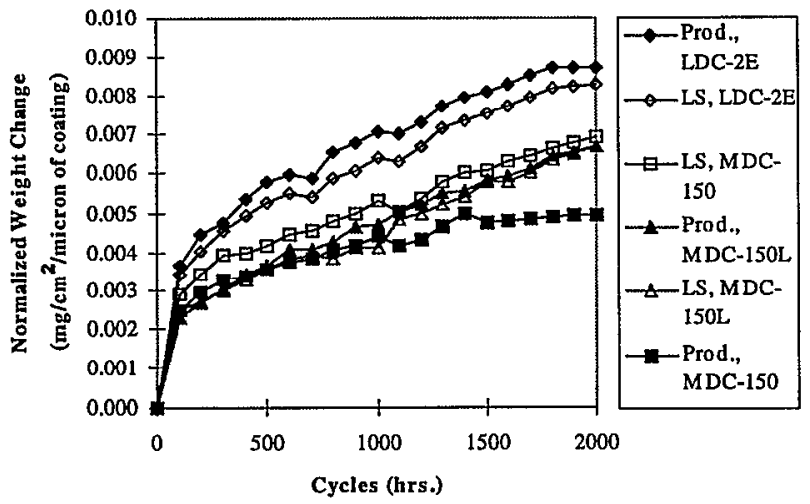

Figure 7: Cyclic oxidation results at $1093^{\circ} \mathrm{C}$ for production and low sulfur versions of Rene' N5.
Weight Change Per Coating Thickness of PW A 1484 Oxidized at $1093^{\circ} \mathrm{C}\left(2000^{\circ} \mathrm{F}\right)$

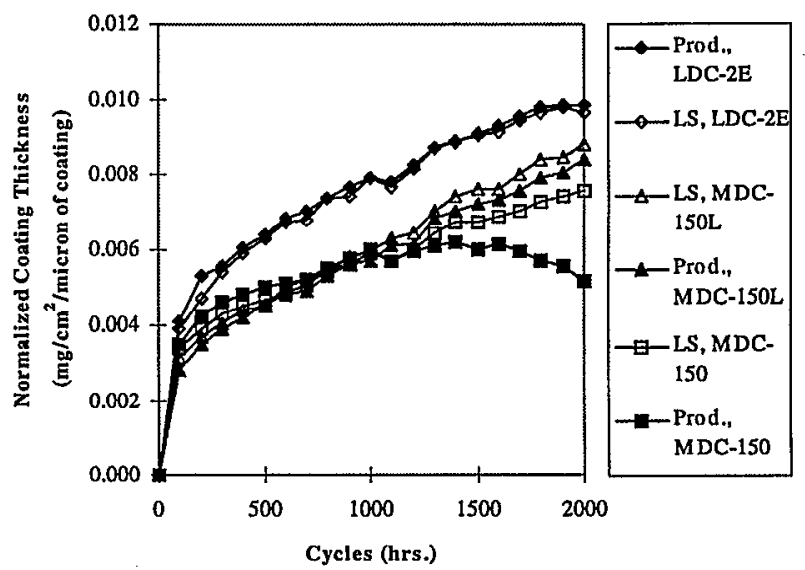

Figure 8: Cyclic oxidation results at $1093^{\circ} \mathrm{C}$ for production and low sulfur versions of PWA 1484.

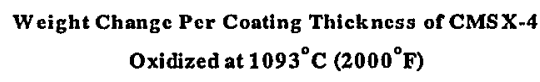
Oxidized at $1093^{\circ} \mathrm{C}\left(2000^{\circ} \mathrm{F}\right)$

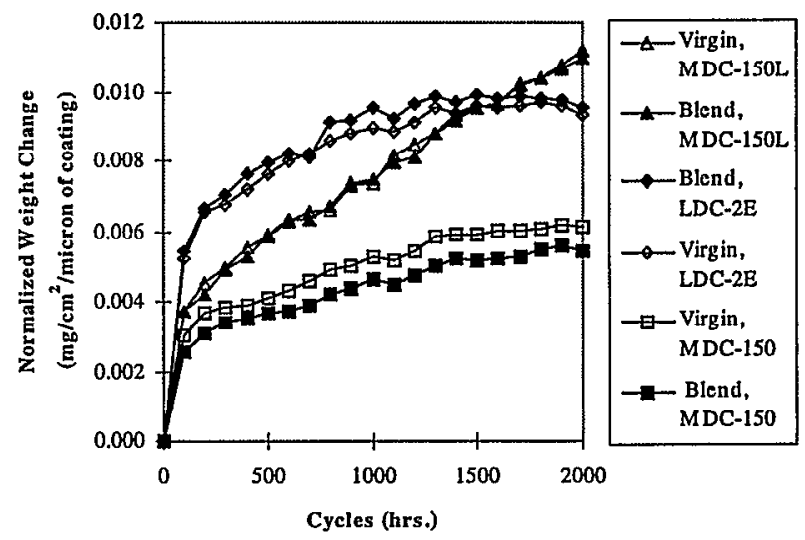

Figure 9: Cyclic oxidation results at $1093^{\circ} \mathrm{C}$ for virgin and blend versions of CMSX-4. 


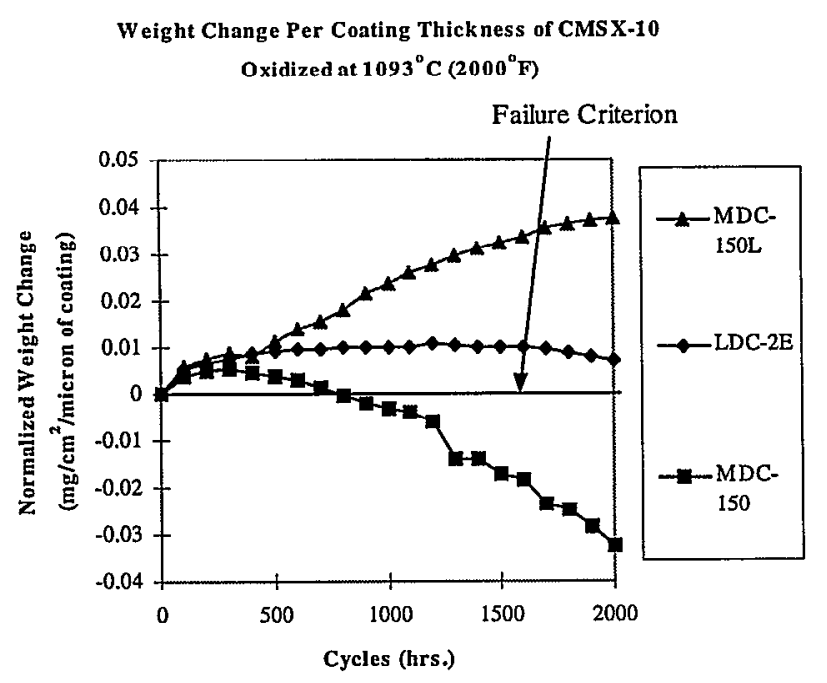

Figure 10: Cyclic oxidation results at $1093^{\circ} \mathrm{C}$ for CMSX-10.

In general, it is evident that the Howmet low sulfur processing and lower sulfur test coupons provided improved oxidation performance for the alloys tested. At $1177^{\circ} \mathrm{C}$ $\left(2150^{\circ} \mathrm{F}\right)$ the low sulfur alloys experienced a smaller weight loss than their production alloy counterparts that have a higher sulfur content. However, at $1093^{\circ} \mathrm{C}\left(2000^{\circ} \mathrm{F}\right)$, the driving force for oxidation was not as great, and therefore protective layer spallation was not a problem up to 2000 hours. Thus, most of the alloys at that testing temperature experienced only weight gain. The sulfur content may not affect the oxidation resistance of the alloys at $1093^{\circ} \mathrm{C}$ $\left(2000^{\circ} \mathrm{F}\right)$ until exposed for a longer time period.

\section{Conclusions}

Alloys with a sulfur level of less than one ppm were produced using a liquid refining method developed at Howmet Dover Alloy. Reducing the amount of sulfur present in the nickel based superalloys did increase the oxidation resistance especially at $1177^{\circ} \mathrm{C}\left(2150^{\circ} \mathrm{F}\right)$. The increase in oxidation resistance with reduced sulfur content was more apparent with the LDC-2E and MDC-150 coatings rather than the MDC-150L coating. All three of the coatings used in the evaluation appeared to be especially effective at limiting alloy corrosion at $1093^{\circ} \mathrm{C}\left(2000^{\circ} \mathrm{F}\right)$ up to 2000 hours.

\section{Acknowledgments}

The authors would like to acknowledge Dr. Bruce Warnes of Howmet Thermatech Coating for informative technical discussions. In addition, Rebecca Boczkaja is acknowledged for running all of the oxidation tests and evaluating the oxidation coupons.

\section{$\underline{\text { References }}$}

1. Chester Sims, Norman Stoloff, and William Hagel, Superalloys II - High Temperature Materials for Aerospace and Industrial Power (New York, NY: John Wiley and Sons, 1987), 301.

2. C. Sarioglu et al. "The Control of Sulfur Content in Nickel-Base, Single Crystal Superalloys and Its Effects on Cyclic Oxidation Resistance," Superalloys 1996, 71-80.

3. James Smialek, "Toward Optimum Scale and TBC Adhesion on Single Crystal Superalloys," Electrochemical Society Proceedings, 98-99.

4. Jeffrey Irvine et al., "Ultra Low Sulfur Superalloy Castings and Method of Making," U.S. Patent \# 5,922,148 July 13, 1999.

5. B. Warnes, "Improved Pt Aluminide Coatings Using CVD and Novel Platinum Electroplating" (Paper presented at Intcrnational Gas Turbine and Aeroengine Congress and Exhibition, Sweden, 1998 ASME 98-GT-391). 